International Journal of Social Sciences and Humanities
Available online at http://sciencescholar.us/journal/index.php/ijssh
Vol. 2 No. 3, December 2018, pages: 187 195
e-ISSN: 2550-7001, p-ISSN: 2550-701X
https://doi.org/10.29332/ijssh.v2n3.235

\title{
Student Anxiety and Their Speaking Performance: Teaching EFL to Indonesian Student
}

\begin{abstract}
CrossMark
Santri E.P. Djahimo a, Dewi I.N. Bili Bora ${ }^{\text {b }}$, Elisna Huan ${ }^{c}$

Article history: Received 9 April 2018, Accepted: 30 August 2018, Published: 20 December 2018

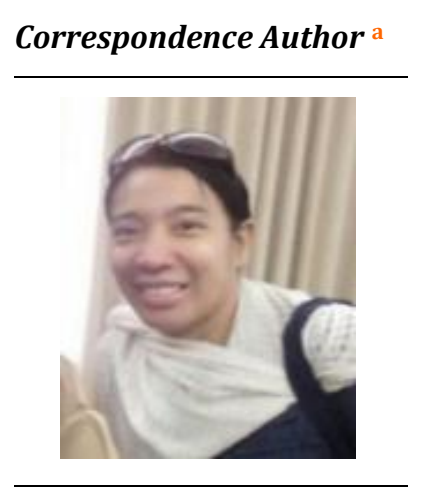

Keywords

anxiety;

case study;

EFL students;

Indonesian students;

Abstract

This study aims at finding out whether or not there's an impact on students' anxiety on their speaking performance. In addition, it also has an aim to identify factors relate to students' reluctance that can hinder their oral performance. Observation, interview, and questionnaire have been used to collect the data which has then been analyzed in a qualitative way. 25 students of the second semester of English Department Universitas Nusa Cendana Indonesia have been selected as the subject of this research. Based on the findings and analysis, it can be revealed that students' anxiety definitely has an impact on their speaking performance and this becomes one of the reasons why they find it difficult to express themselves in English. Many factors have been identified but only those which have been considered as the main ones are presented in this writing to answer the question of why the students have been reluctant in their oral performance. Knowing that their oral performance was severely hampered by the above-mentioned factors, several solutions have been recommended to make them easy to cope with their anxiety.
\end{abstract}

speaking performance;

e-ISSN: 2550-7001, $p$-ISSN: 2550-701X ${ }^{\circ}$ Copyright 2018. The Author. SS Journals Published by Universidad Técnica de Manabí. This is an open-access article under the CC BY-SA 4.0 license (https://creativecommons.org/licenses/by-sa/4.0/) All rights reserved.

\section{Contents}

Abstract 187

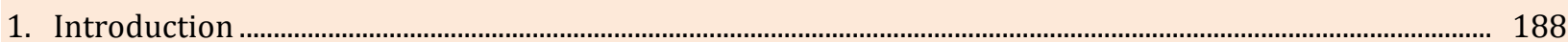

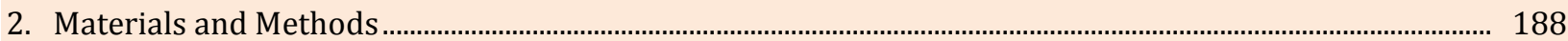

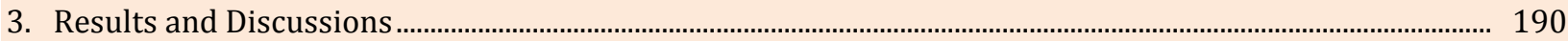

3.1 Students' Anxiety and their Speaking Performance .......................................................................................... 190

3.2 Problems that can Hinder Students' Oral Performance....................................................................................... 191

\footnotetext{
a English Study Program, Universitas Nusa Cendana, Kupang, Indonesia

b English Study Program, Universitas Nusa Cendana, Kupang, Indonesia

c English Study Program, Universitas Nusa Cendana, Kupang, Indonesia
} 


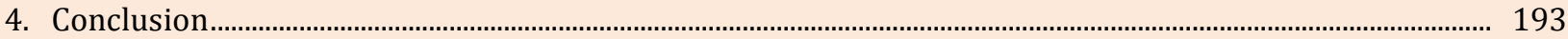

Acknowledgements................................................................................................................................................. 193

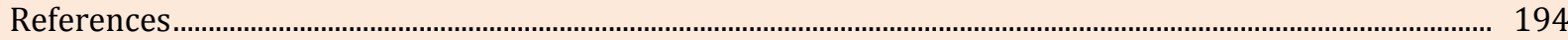

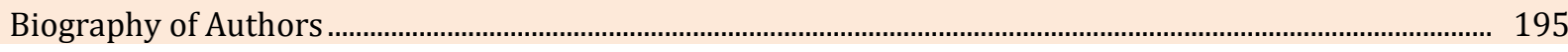

\section{Introduction}

Knowing a language is being able to speak it is one of the reasons why speaking skill is important to be learned by either ESL or EFL learners. Besides, in communicating their ideas orally students need this skill to get their messages across. There are still many other good reasons why speaking as one of the productive skills needs to be included in school or course curriculum to be taught by teachers.

In teaching speaking, many teachers have made much effort to find good methods, strategies, techniques, media and teaching materials to make the most of it. They have tried hard to maximize every way in the teaching and learning process. However, many students still think that speaking is the most difficult skill they have to deal with. Students of high schools don't really focus on this skill because they have to learn all integrated skills. Moreover, several EFL school teachers think that it's not necessary to teach speaking skill separately in junior or senior high schools because it won't be tested in either school or national exams. This implies that speaking is not considered an important skill to be learned by students of high schools. Why speaking isn't really considered to be tested in many school exams because according to Clifford (1987), it's not easy to be objectively assessed and time-consuming. Although speaking skill is neglected in many exams, people still believe that the ability to speak in the target language is the way to measure whether or not learners are successful in their learning process (Nunan, 1995).

When students come to a higher degree (i.e. English Department), they have speaking skill as a core unit and compulsory subject to be taken. In this subject, many students find it difficult to deal with their oral performance and can't perform well. Obviously, it can be seen that students' reluctance in their oral performance is caused by various factors which are going to be identified through this study. Besides, problems encountered by them will also be discussed and elaborated here.

\section{Materials and Methods}

On this section, we present literature review and methods we applied in conducting the study. Language learners will agree that speaking skill is important to be learned in order to be able to communicate in the target language. However, many EFL students think that being able to speak good English is not an easy process because speaking is considered the most difficult skill to be mastered (Brown et al., 1983). Teachers have to make much effort to deal with this condition.

The issue about students' difficulties in their speaking performance has been raised by many people and a lot of concern has been shown in the forms of studies, researches, and writings. Many experts have particularly looked at students' problems in speaking class from various angles. Most of them have tried to find solutions over those problems because the basic principle of teaching speaking is to make students use the language actively in communication. Ruan (2018); Dossoumou et al., (2018), Nehe et al., (2018), Ngadi et al., (2018), Hounhanou (2018), this is an essential starting point that has to be applied by EFL teachers and/or lecturers in teaching speaking. In order to make students speak good, fluent, and accurate English, teachers have to really understand the source of problems their students encounter in the teaching and learning process. Teachers have to find out factors which can potentially influence their students' speaking performance.

There are many influential factors that can contribute to students' poor performance in speaking. However, only the main factors will be discussed here, such as performance conditions, affective factors, listening ability, topical knowledge, and feedback during speaking activities (Tuan \& Mai, 2015):

1) The issue of performance conditions is the first factor that can really influence students in performing their speaking ability. Different performance condition can have a different result. Nation \& Newton (2009), strengthen this point by stating that all types of performance conditions (time pressure, 
planning, the standard of performance, and the amount of support) can have an impact on students' oral performance.

2) A set of effective factors is the second important issue dealing with students' affective domain. The effective side of language learning is very important to be taken into account (Oxford, 1990). Many aspects have been included in affective factors but the most popular ones are anxiety, motivation, and self-confidence (Krashen, 1982).

3) How speaking and listening skills relate to each other comes as the third factor, called listening ability. One has to be able to receive well (through listening) in order to produce better (through speaking) (Doff, 1998; Shumin, 1997). This describes how close speaking and listening is. If speakers can't comprehend what they are listening to, then there'll be no communication as they won't be able to respond.

4) The next factor is topical knowledge. This factor is no less important than others because without having (good) knowledge about topics which are being discussed, students won't be able to interact and participate in the teaching and learning process. Topical knowledge isn't only about how students master the language they are learning but also about their knowledge about the world in general (Bachman \& Palmer, 1996). It's useless if students can speak the target language but don't have enough knowledge to share.

5) Feedback during speaking activities comes as the last but not least factor. This issue is quite tricky for teachers because when they give feedback in the middle of students' presentation, they will distract them from their concentration and they might not be able to continue. However, if they decide to give feedback after the presentation, students might forget about the errors and/or mistakes they've committed in their presentation. In this case, teachers have to be very careful to decide when the right time to give feedback to students is, otherwise, they will be demotivated and this will make them stop talking (Harmer, 2001; Baker \& Westrup, 2003).

Those factors discussed above have become the basic elements for data analysis in this writing. Besides, problems usually encountered by students in their oral performance are also identified to be able to find solutions.

There are 4 main problems quoted from Tuan \& Mai (2015) which will be discussed here and they will be used in this study as well, they are inhibition, lack of topical knowledge, low-participation, and mother-tongue use. Inhibition is dealing with students who can't perform well because they are shy and nervous and afraid of being assessed or judged by not only their teachers but also their friends when they make mistakes. This happens because these students feel that their friends are better than they are. The second problem is the lack of topical knowledge. This is more or less similar to the fourth factor (topical knowledge) mentioned earlier. Students do not have anything to say because they don't understand about the topic, so they can't say anything relates to the content of the discussion. Another problem with this lack of topical knowledge is students also have a lack of vocabulary that can prevent them from expressing what there are thinking (Baker \& Westrup, 2003). Low participation in the third problem usually encountered by students in speaking class. This mostly happens to classes with a big number of students. In this case, not every student has enough time to talk because of the time limit. There might be students who never talk during the speaking class because other students or even teachers dominate the talk. The last and most popular problem in speaking is mothertongue use. This is a kind of general practice which usually occurs in EFL/ESL speaking classes. Students who speak similar native languages will tend to use their mother-tongue because it's easier for them to communicate and share ideas, especially at the time when they lose their ideas and/or don't know what to say due to limited vocabulary.

Next, related to the research, this study has been conducted for one semester (16 meetings). The data has been collected by employing several instruments; they are observations, interviews, and questionnaire. The respondents are 25 students of the second semester of English Department of Nusa Cendana University.

Class observations have been carried out in order to see students' speaking performance, particularly, their reluctance in delivering their oral presentation. In finding out whether or not students' anxiety has impacts on their speaking performance, a set of the questionnaire has been delivered to these 25 students to be filled in. The questions in the questionnaire are mainly about what they think about their speaking performance, what problems they think they have during their presentation, what factors they think have great influence on their

Djahimo, S., Bili Bora, D., \& Huan, E. (2018). Student anxiety and their speaking performance: teaching EFL to Indonesian student. International Journal of Social Sciences and Humanities, 2(3), 187-195. https://doi.org/10.29332/ijssh.v2n3.235 
performance. 10 out of 25 students have then been selected randomly to be interviewed. The purpose of the interview is to allow students to elaborate their answers in a more complete way. All the data gained have then been analyzed qualitatively in order to answer whether or not there's an impact of students' anxiety on their speaking performance as well as to identify factors and problems relate to students' reluctance that can hinder their oral performance.

\section{Results and Discussions}

The followings are the detailed analysis regarding findings and discussion of this study which consists of two parts; students' anxiety and their speaking performance and problems that can hinder students' oral performance. The data of the findings is presented in the form of pie charts and so the level of percentage will be clearly seen.

\subsection{Students' Anxiety and their Speaking Performance}

During the observations, it has been noted that most students could not perform well in their performance due to their psychological reactions. Several obvious and visible signs about their performance have been noted, they are: they made many unnecessary errors and/or mistakes regularly, they couldn't speak fluently because they paused awkwardly (stuttering and/or cluttering), they couldn't continue their presentation because they started sweating and panic and so they lost control over what they would say (going blank), they used or inserted their native language in the middle of their presentation because they didn't know the word(s) and/or expression(s) in English (lack of vocabulary), few of them just kept silent and didn't say a word during their presentation time. It has also been noted that several students showed their behavioral reactions, such as stammering, fidgeting, trembling, procrastination, and avoidance behavior which made them uneasy in their performance.

The above-mentioned phenomena have also been strengthened by the students' answers in the questionnaire and interviews related to influential factors in their speaking performance. They have come up with the level of percentage of various factors which have then been grouped into 5 categories based on what has been stated by Tuan \& Mai (2015:9-10), they are performance conditions (time pressure, planning, the standard of performance, and the amount of support); affective factors (motivation, self-confidence, and anxiety) which have also been classified as psychological factors (Aouatef, 2015; Brown, 1994), listening ability; topical knowledge; and feedback during speaking activities. The big picture of the students' answers can be found in the pie charts below:

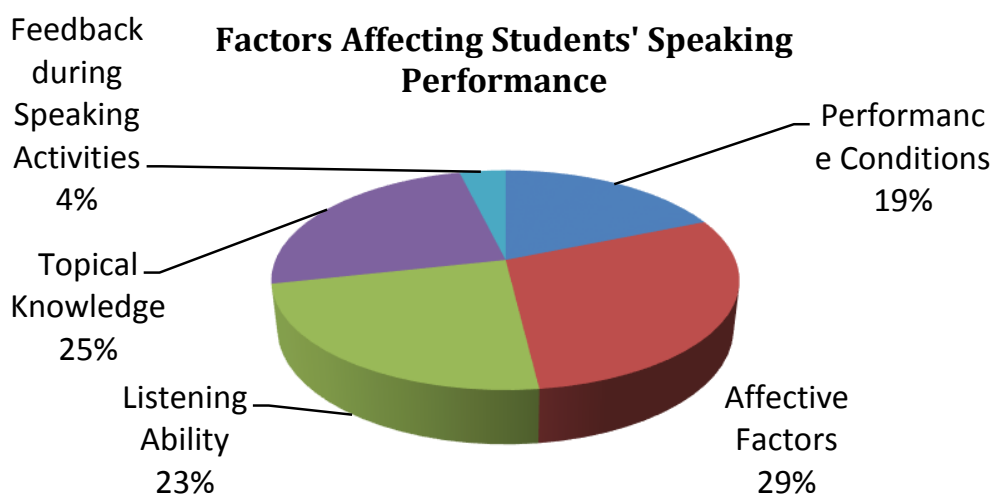

Figure 1. The student's answers

Based on the students' answers about influential factors in their speaking performance, the category of affective factors is on the top level of their choice (29\%), followed by topical knowledge (25\%), listening ability (23\%), performance conditions (19\%), and feedback during speaking activities (4\%). Since this 
analysis has indicated affective factors to be the most significant factor that has influenced the students' speaking performance, the discussion will only focus on affective factors.

Affective factors contain three important aspects, namely motivation, self-confidence, and anxiety. In order to find out which aspect is more dominant, the students have also been asked to give their opinion about the most influential aspects that can hinder their oral performance. The data that shows their answers can be found in the following chart:

Affective Factors

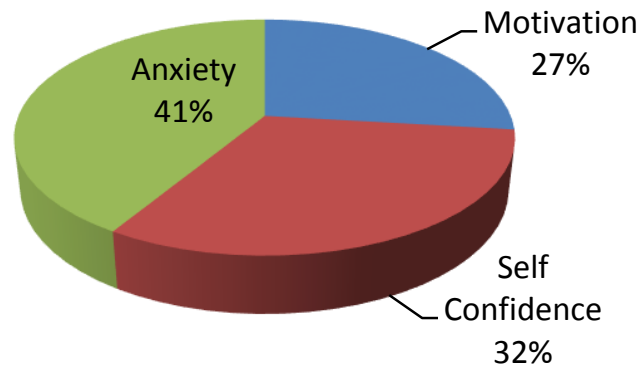

Figure 2. The student's opinion about the most influential aspects

It's clearly seen from the chart that anxiety is the most influential factor which has severely debilitated their speaking performance (41\%), followed by self-confidence (32\%), and motivation $(27 \%)$. These numbers of percentages have also been supported by students' answers in the interview section. Most of them agree that anxiety is the most dominant factor in influencing the students' speaking performance.

Based on the findings, it can be positively said that there's an impact on students' anxiety on their speaking performance. Those who have low-level of anxiety perform better than the ones with high-level of anxiety. This happens because the low-level anxiety students have high-motivation and self-confidence to help them perform better. This finding is in accordance with Krashen's affective filter hypothesis in which he claims that language learners with low-level of anxiety and high-motivation and self-confidence will do better in learning and/or acquiring a language.

Although the main concern of this study is on the issue of anxiety, it doesn't really address and make clear distinctions about types of anxiety (trait and state). This study is only focused on anxiety as a general issue. Considering the facts that students have such kind of psychological and behavioral reactions during their presentations which lead to the poor result of it, an answer to the previous question about whether or not there's an impact of students' anxiety on their speaking performances has already been clearly answered.

\subsection{Problems that can Hinder Students' Oral Performance}

These 25 students have also identified their problems and difficulties in speaking EFL. Types of problems and their percentages can be seen below:

Djahimo, S., Bili Bora, D., \& Huan, E. (2018). Student anxiety and their speaking performance: teaching EFL to Indonesian student. International Journal of Social Sciences and Humanities, 2(3), 187-195. https://doi.org/10.29332/ijssh.v2n3.235 


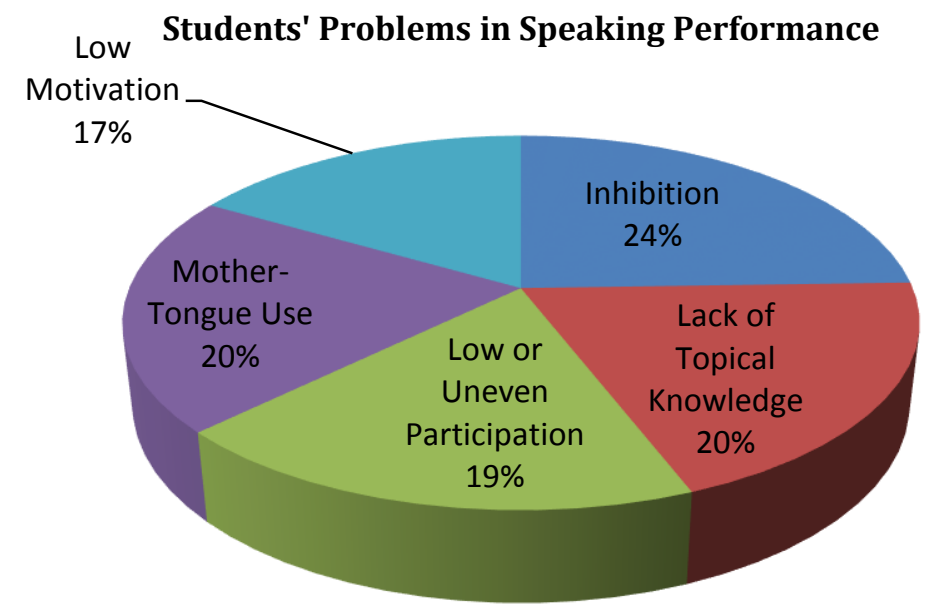

Figure 3. The students identified their problems and difficulties in speaking EFL

It can be read from the pie chart that students' most dominant problem is inhibition (24\%), followed by lack of topical knowledge (20\%) and mother-tongue use (20\%), low or uneven participation (19\%), and low motivation (17\%).

When they're asked about their major problem in their speaking performance, all of them said that they're shy and nervous about making mistakes. The extracts of interviews are presented below:

Interviewer : Why do you think you can't do well in your speaking performance?

Student $1 \quad$ : I feel nervous every time I have to stand in front of the classroom and talk. I always think I'm stupid and not as good as my other friends and this makes me hard to open my mouth and say a word.

Student $5 \quad$ : I'm shy and afraid of making mistakes. I don't want my friends to laugh at me.

Student $8 \quad$ : My English isn't good and that makes me shy to talk in front of my friends. I feel like I'm the most stupid student in the classroom every time I make mistake.

Actually, these inhibition problems (Ur, 1996), can be overcome if these students have a good level of selfconfidence. They don't believe in themselves and always feel that they can't compete with their other friends. These can trigger off their anxiety and will make them uneasy to do their oral presentation.

Not knowing what to say or loss of ideas about the topics to be discussed or presented is another problem mostly faced by these students. It's also known as lack of topical knowledge (Ur, 1996). The extracts can be found below:

Interviewer : Do you understand all topics discussed in speaking class?

Student $2 \quad$ : Sometimes I don't understand what my lecturer is talking about so I just sit quietly and listen to them.

Student $4 \quad$ : I don't like talking if I don't understand the topic. If I have to talk then I'll go to the wrong directions and my friends will laugh at me.

Student 10 : There are several topics which are difficult for me to understand. I don't want to ask my lecturer to explain because everybody else doesn't ask and I'm too shy to do that.

If students don't really know about the discussion or presentation topic then they will have very little, if not nothing to say. This lack of topic knowledge will lead them to other problems; they are low or uneven participation, low motivation, and mother tongue use (Ur, 1996). 
In another side, when they have nothing to say, they will tend to be ignorant, just sit and listen to others passively without participating and interacting, and this can be seen in the following extract:

Interviewer : What do you usually do if you don't understand what is being discussed?

Student 3 : Nothing. I just sit quietly and listen to my lecturer.

Student $7 \quad$ : I try to focus on the topic, but if I still can't follow it, I'll give up and let it go.

Student 9 : I'll ask my lecturer to explain. If I don't know how to ask in English, I'll use Bahasa Indonesia.

From their answers in the interviews, it can be assumed that having one problem (i.e. inhibition) will lead them to other problems (lack of topical knowledge, low or uneven participation, mother-tongue use, and low motivation) which eventually will give impact on their speaking performance. Since the root of the students' problems relates much to psychological factors, they have to be treated in psychological ways, such as keep on motivating them to improve their speaking skill and other supporting skills (reading and listening) and components (grammar, vocabulary and pronunciation) as well as giving them positive feedback about their good work, no matter how small it is, in order to increase their self-confidence. Additionally, the low-pressure situation has to be created in facilitating students when they want to practice their speaking skill. By having a low-pressure situation, students will be more relaxed and might have better control over their performance. Another important solution is an encouragement. Students need to be encouraged all the time to make them feel secure. Once they've had the feeling, they can feel free to express whatever they want to say in their performance.

\section{Conclusion}

Having poor quality in speaking performance doesn't make students stop being learners. They still have a chance to learn more and improve their skill through their teachers and themselves. The quality of their performance is basically affected by various influential factors and problems mentioned earlier which make them uneasy, fearful, uncomfortable and demotivated in delivering their tasks.

Relating to the above-mentioned phenomenon, teachers and/or have to find strategies to create positive learning atmosphere which can help their students out of their comfort zones and start changing themselves to be braver, have more self-confidence and comfortable in delivering their presentation. Another important task has to be done by teachers and lecturers is to find relaxed and joyful ways to keep their students motivated and engaged in all speaking tasks assigned. By having good motivation, they can improve their oral performance better.

\section{Acknowledgments}

The authors would like to thank the reviewer of the journal for their consideration accepted this article. As well as thank the editor for their valuable time, advice and support. This work was financed by personal funding.

Djahimo, S., Bili Bora, D., \& Huan, E. (2018). Student anxiety and their speaking performance: teaching EFL to Indonesian student. International Journal of Social Sciences and Humanities, 2(3), 187-195. https://doi.org/10.29332/ijssh.v2n3.235 


\section{References}

Aouatef, Belegdair. (2015). The Main Psychological Factors Affecting Learners' Oral Performance, Case Study: Second year LMD Students of English. Mohamed Kheider University of Birska.

Bachman, L. F., \& Palmer, A. S. (1996). Language testing in practice: Designing and developing useful language tests (Vol. 1). Oxford University Press.

Baker, J., \& Westrup, H. (2003). Essential speaking skills. A\&C Black.

Brown, G., Gillian, B., \& Yule, G. (1983). Teaching the spoken language (Vol. 2). Cambridge University Press.

Brown, H. D. (1994). Principles of language learning and teaching.

Clifford, R. T. (1987). Language teaching in the federal government: A personal perspective. The Annals of the American Academy of Political and Social Science, 490(1), $137-146$. https://doi.org/10.1177\%2F0002716287490001010

Doff, A. (1998). Teach English: A Training Course for Teacher. Cambridge: Cambridge University Press.

Dossoumou, A. M., Mehouenou, M. S., \& Koukpossi, A. O. (2018). Appraising the impacts of cohesion and coherence in Benin SS3 EFL learners' writing productions. International Journal of Linguistics, Literature and Culture, 4(5), 41-54. https://doi.org/10.21744/ijllc.v4n5.293

Harmer, J. (2001). The practice of English language teaching. London/New York.

Hounhanou, A. V. (2018). Evaluating Benin EFL Learners Writing Composition during Final Exam. International Journal of Linguistics, Literature and Culture (IJLLC), 4(2), 9-23.

Krashen, S. D. (1982). Principles and practice in second language acquisition.

Nation, I. S. P., \& Newton, J. (2009). Teaching ESL/EFL listening and speaking. ESL \& Applied linguistics professional series. Routledge Taylor \& Francis Group.

Nehe, B. M., Mayuni, I., \& Rahmat, A. (2018). Using sociodrama in EFL speaking class. International Journal of Linguistics, Literature and Culture, 4(4), 44-52. https://doi.org/10.21744/ijllc.v4n4.262

Ngadi, Y. F., Tans, F., \& Bustan, F. (2018). Questions and answers in EFL classroom. International Journal of Linguistics, Literature and Culture, 4(6), 7-16. https://doi.org/10.21744/ijllc.v4n6.329

Nunan, D. (1995). Language Teaching Methodology: A Textbook for Instructors. English Language Teaching.

Oxford, R. (1990). Language learning strategies. New York, 3.

Ruan, X. (2018). Engagement and negotiation: Exploring a tertiary female EFL teacher's professional agency in her career development in PR China. International Journal of Linguistics, Literature and Culture (IJLLC), 4(3), 46-63.

Shumin, K. (2002). Factors to consider: Developing adult EFL students' speaking abilities. Methodology in language teaching: An anthology of current practice, 12, 204-211.

Ur, P. (1996). A course in language teaching: Theory and practice. Great Britain.

Vietnam, V. (2015). Factors affecting students'speaking performance at le thanh hien high school. Asian Journal of Educational Research Vol, 3(2). 


\section{Biography of Authors}

\begin{tabular}{|l|l||}
\hline \hline & $\begin{array}{l}\text { Santri E.P. Djahimo is a senior lecturer at Universitas Nusa Cendana Kupang NTT, } \\
\text { Indonesia. She has got her Master degree and her Ph.D. from Macquarie } \\
\text { University, Sydney-Australia. Besides teaching, She is also active in conducting } \\
\text { researches on EFL Class area. Beside interested in EFL, she is also interested in } \\
\text { Linguistics. } \\
\text { Email: sunthree_dj@yahoo.com }\end{array}$ \\
\hline \hline & $\begin{array}{l}\text { Dewi I. N. Bili Bora is a lecturer at Universitas Nusa Cendana Kupang NTT, } \\
\text { Indonesia. Besides teaching, she is also in conducting scientific researches. Her } \\
\text { interest is in TEFL. } \\
\text { Email: dewi.bilibora@yahoo.co.id }\end{array}$ \\
\hline & $\begin{array}{l}\text { Elisna Huan is a lecturer at Universitas Nusa Cendana Kupang NTT, Indonesia. } \\
\text { Besides teaching, she is also active in conducting researches. Her interest is in } \\
\text { Linguistics. } \\
\text { Email: elisnahuan@gmail.com }\end{array}$ \\
\hline
\end{tabular}

Djahimo, S., Bili Bora, D., \& Huan, E. (2018). Student anxiety and their speaking performance: teaching EFL to Indonesian student. International Journal of Social Sciences and Humanities, 2(3), 187-195. https://doi.org/10.29332/ijssh.v2n3.235 